\title{
Commercial Policy's Trade Facilitation Effects on Cost of Operations as Determinants of Multinational Corporations Employability
}

\author{
Akinbola, Olufemi Amos \\ Department of Business Administration, \\ College of Management Sciences, \\ Federal University of Agriculture, Abeokuta \\ Issa, Abdulraheem Ph.D \\ Department of Business and Entrepreneurship, \\ Kwara State University, Malete. \\ Brimah, Aminu Nassir Ph.D \\ Department of Business and Entrepreneurship, \\ Kwara State University, Malet
}

\begin{abstract}
This study examined commercial policy's trade facilitation effects on employability of multinational corporations in Nigeria considering whether trade facilitation $(T F)$, has a significant effect on the multinational Corporations employability expressed in cost of operation (COP). The study adopted cross sectional research design and considered 5 multinational corporations in the food and beverage and conglomerate sub-sector in Nigeria based on random sampling technique by employing primary data. The sample size constituted the lower, middle and senior level staff of the multinational Corporations at their headquarters and plants to achieve the objectives of this study based on the hypothesis that was formulated. Both descriptive and inferential statistical techniques were employed. The statistical tools used included cross tabulations, Mean, Regression and Correlation analysis with the aid of SPSS computer packages. The results showed that trade facilitation (TF) have significant effect on cost of operation (at $P=0.000$ ). In conclusion, the study reflected that each of the performance indicators under consideration related with commercial policy and employability implies the need for compliance by multinational corporations to be ensured as governmental follow up in areas of trade facilitation is pertinent to employment creation. The study recommends that; government is encouraged to continue to play her regulatory, facilitating and participatory roles to foster an enabling operating environment as it will contribute towards firm competitiveness in the domestic and global marketplace.
\end{abstract}

KEYWORDS: Trade Facilitation, Multinational Corporations, Cost of Operation, Employability.

\subsection{Introduction}

Hur and Park (2012), considers commercial policy as the part of economic policy of a country, that is related with total measures and instruments that influence business activities, either through regulations, quantities, prices or which goods will be traded or not. It is a strategy used by governments to regulate the process of trade with other countries and within states of a country. The concept of commercial policy is a global phenomenon that compels countries across the globe to adopt initiatives that can protect local industries, encourage foreign direct investment, induce revenue for the government and mitigate unemployment for sustainable development.(Okuyan, Ozun \& Erbaykal, 2012).The idea that commercial policy initiatives leads to economic growth and improves the welfare of the citizens of a country has attracted the attention of policy makers of developing economies in recent years as 
commercial policy embraces all of the varied economic, trade, industrial and production activities of government that bear directly or indirectly upon the composition, direction and magnitude of business and financial operation. The underlying goal of any commercial policy is to establish and maintain equitable trade relations with other countries or localized regions within a country. This is often accomplished by enacting regulations that help to develop local businesses and multinational corporations that are domiciled in the country where such policies are made. The exact nature of those policies vary, depending on the type of industry, goods and services involved, as the purpose of commercial policies is to strengthen the business ties of the country or states involved in the policy framework.

\subsection{Statement of Research Problem}

The desire to expand productive employment is the core of any nations' policies because in many developing nations, unemployment and underemployment have been found to be major causes and consequence of widespread low level of development (Ezie, 2012). The study on trade facilitation and business transaction cost by the United Nations Conference on Trade and Development (UNCTAD, 2014) showed that an average trade transaction between most nations goes through many cumbersome processes which may involve up to 20parties in the value chain requiring at least 40 documents of which 60 to $70 \%$ are repeated in the process time leading to increase cost of doing business which sometimes affect the revenue generation of the firms involved in business activities. Also in moving goods across the states of Nigeria, transportation systems and local tariffs called several names by customs, police and other security officers across several points of movement between a state and another can be discouraging which is a major impediment to trade facilitation of multinationals in the country. Enormous amounts of time and money are wasted because of out-dated business and trade procedures, hampering business, stifling growth and holding back economic development resulting in the capacity of multinationals to create employment due to high cost of doing business and dwindling revenue particularly in developing countries.

The importance of ensuring that trade can flow with minimum impediments, with higher security levels and more efficient government control methods, has been the focus of increasing attention. Trade facilitation is a key element in reducing the cost of operation of multinational as evidences in researches by Persson, (2012) and Azevedo, (2015) showed that cost of operation is a major determinant of employability for certain multinationals. The importance of ensuring that trade can flow with minimum impediments, with higher security levels and more efficient government control methods, has been the focus of increasing attention in Nigeria as Trade facilitation is a key element in improving the business environment.

In essence the study intends to examine the effect of trade facilitation as an element of commercial policy intervention and its influence on cost of operation affecting employability of multinationals.

\section{Hypotheses One}

$\mathrm{Ho}_{1 \mathrm{a}}$ : commercial policy's Trade facilitation does not significantly affect cost of operation of multinationals

\subsection{Review of Literature on Trade Facilitation}

The term 'trade facilitation' can be defined as 'the simplification and harmonisation of international trade procedures'. These procedures include the 'activities, practices and formalities involved in collecting, presenting, communicating and processing data required for the movement of goods between countries or within a country'. Clearly, this definition relates to a wide range of activities including but not limited to import and export procedures (for example, customs or licensing procedures), transport formalities, payments, insurance, and other financial requirements. However, the definition of trade facilitation has been broadened to include the transparency and professionalism of customs authorities, harmonisation of various standards and conformity to international or regional regulations. In a narrower sense, trade facilitation concerns the movement of goods in cross-border trade.

Nowadays trade costs associated with transportation charges, documentation requirements and delay in clearance at a national border are as important as traditional border such as tariffs and quantitative restrictions. The ability of countries to deliver goods and services in time and at low costs is a key determinant of their participation in the global economy. Easier movement of goods and services clearly drives export competitiveness and fosters diffusion of better technologies through imports and foreign direct investment. Increasing awareness of those trade-related transactions costs has called for multilateral rule making and regional coordination regarding trade facilitation. 
Trade facilitation is expected to have a favourable impact on trade expansion and hence economic development just as trade liberalization in a traditional sense - a removal of tariffs and quantitative restrictions. According to Rudaheranwa, (2006), trade facilitation can be viewed in narrow or broad terms, and in unilateral or multilateral terms. In narrow and unilateral terms, improving the movement of goods through one's own customs appears to be improving the importation of goods rather than the exportation of goods. Even in this limited perspective, however, trade facilitation can have important implications for the ease and efficiency of lowering of barriers to trade having pro-export effects has even more relevance when all types of policy and other barriers are considered. In this regard barriers other than customs procedures (e.g. transport infrastructure and competitiveness of transport and other services) may be more important for some countries. Also in the world ease of Doing Business data by World Bank, Nigeria ranks 169 out of 196 countries in the world making it one of the most difficult countries to conduct business.

Table: 2.1.2 Global Ranking on Ease of Doing Business

\begin{tabular}{|c|c|c|c|c|}
\hline $\mathrm{S} / \mathrm{N}$ & CONTINENT & COUNTRY & RANKING & $\begin{array}{l}\text { DTF } \\
\text { SCORE }\end{array}$ \\
\hline 1 & AFRICA & Morocco & 68 & 67.50 \\
\hline 2 & AFRICA & Nigeria & 169 & 44.63 \\
\hline 3 & ASIA & China & 78 & 64.28 \\
\hline 4 & ASIA & Arabia & 94 & 61.11 \\
\hline 5 & EUROPE & $\begin{array}{l}\text { United } \\
\text { Kingdom }\end{array}$ & 7 & 82.74 \\
\hline 6 & EUROPE & Germany & 17 & 79.87 \\
\hline 7 & $\begin{array}{l}\text { NORTH } \\
\text { AMERICA }\end{array}$ & * Canada & 22 & 78.57 \\
\hline 8 & $\begin{array}{l}\text { NORTH } \\
\text { AMERICA }\end{array}$ & $\begin{array}{ll}\text { States } & \text { United } \\
\end{array}$ & 8 & 82.45 \\
\hline 9 & $\begin{array}{l}\text { SOUTH } \\
\text { AMERICA }\end{array}$ & + Chile & 57 & 69.56 \\
\hline 10 & $\begin{array}{l}\text { SOUTH } \\
\text { AMERICA }\end{array}$ & Colombia & 53 & 70.92 \\
\hline
\end{tabular}

Source: World Bank, (2016).

Keyword: DTF Score (Distance to Frontier Score) the distance frontier scope is an assessment of the absolute level of regulatory performance over a specific period of time. It helps to measure the distance of each economy to the observed benchmark across all economies in doing business.

\subsubsection{Benefits of Trade Facilitation}

Efficient trade facilitation (e.g. increasing the efficiency of border procedures) can help lower trade transaction costs and employability capacity of multinationals; hence reduce the margin between domestic and international prices to benefit consumers and producers. In some case increasing efficiency of border procedures may require simple reorganization of tasks and procedures, whilst in others it might require investment in infrastructure and human resources. The general economic environment also plays an important role - for example, the availability of 
functioning basic infrastructure such as communication facilities and stable energy supply. OECD (2016) examines the economic impact of trade facilitation and in particular the link between trade facilitation and trade flows, government revenue and foreign direct investment.

\subsubsection{Transport Costs and Trade Facilitation}

Transport costs are clearly an important element of trade costs and amenable to addressing under TF reforms, although transport itself is not often explicitly included. Transport costs are likely to be relatively high for ACP countries: in the Caribbean they are mostly small island economies, in the Pacific they are additionally remote, and costs in Africa are known to be especially high. Recent studies have estimated the level of transport costs in Uganda (Milner et al, 2000; and Tanzania (Kweka, 2006). The implicit subsidy (effective protection) on imports and implicit tax on exports due to transport costs is calculated and compared for the early/mid-90s and early 2000s. The results show that transport costs remain very high, and in particular are a significant cost (tax) to exporters, although there are instances of reductions in freight charges and, more importantly, of significant reductions in transport times.

\subsubsection{Evidence on the Benefits of Trade Facilitation}

The mechanisms by which trade facilitation can promote economic gains are well known. Taking the broad definition in which trade facilitation is any policy action that reduces trade costs shows that the key lies in an understanding of the factors that impede bilateral trade. (Denisia, 2010).Trade costs drive a wedge between export and import prices. As a result of this wedge, producers export less than they would in a world with lower trade costs, and consumers purchase less of each traded product, as well as a narrower range of products, than they otherwise would. Trade facilitation, which reduces the size of this wedge, therefore brings producers and consumers in different countries into closer contact, and tends to increase producer surplus in exporting countries, and consumer surplus in importing countries. Trade facilitation supports the process of economic integration through trade, which can, under appropriate circumstances, lead to rising national incomes, faster productivity growth, and poverty reduction.

\subsubsection{Locational Determinants of Multinationals}

A vast literature has emphasized the impact of location traits and, to a lesser extent, firm traits (Alcacer \& Chung, 2010) on location choices. Nevertheless, recent anecdotal evidence suggests there are differences between firms' geographic expansion strategies, in terms of timing and location selection, that are richer and more complex than the current literature reflects. For example, some firms prefer peripheral markets and postpone entry to attractive markets until they develop capabilities to defy incumbents. When firms expand into new geographic markets, they have a vast set of common options from which to choose. But entering a new market requires resources, so firms are limited in the number of markets they can enter simultaneously in a given period of time. In effect, a firm that chooses one new geographic market is also postponing entry into other potential markets, giving competitors leadtime to improve their competitive positions in those markets. This trade-off between the benefits of entering and the opportunity costs of postponing determines whether firms will choose a location strategy that avoids competitors or one that collocates with them.

\subsubsection{Concept of Unemployment and Employability}

Every economy is characterized by both active and inactive populations. The economically active ones are referred to as the population willing and able to work, and include those actively engaged in the production of goods and services and those who are unemployed. The International Labour Organization (ILO, 2014) defines the unemployed as numbers of the economically active population who are without work but available for and seeking work, including people who have lost their jobs and those who have voluntarily left work. De Hoyos et al., (2012). Clarifies 'employability' as 'the quality of being employable'. More broadly, it can be conceptualized as 'gaining, sustaining and progressing in employment'. Significant enabling factors for employability include labour market policy and active labour market programmes that enhances employability skills' human resource management practices.

\subsection{Inference to Comparative Advantage Theory}

This research holds its footings on the theory of comparative advantage which is the ability of a firm or individual to produce goods and/or services at a lower opportunity cost than other firms or individuals. A comparative advantage gives a company the ability to sell goods and services at a lower price than its competitors and realize stronger sales margins. In essence MNCs would locate their businesses where good and services are easily transferred with less cost and also situate where they can get access to affordable labour as cost of operation affects employee overheads. 
The role of multinationals can thus be seen as to exploit the home country's comparative advantages in intermediate inputs that are embodied in products whose final stages of production give a comparative advantage to the host country (Dunning, 1993a). This is a most significant suggestion: some factor endowments generate comparative advantages that are better exploited abroad. That is, firms can build their competitive advantages upon the home country's specific location-advantages, but best exploit these advantages, partially or totally, abroad, an idea also developed by Dunning (2009). 'Competitive advantage is at the heart of a firm's performance in competitive markets. However, many firms lost sight of competitive advantage in their scramble for growth and pursuit of diversification. Today the importance of competitive advantage could hardly be greater as firms throughout the world face slower growth.

\subsection{Empirical Framework}

\subsubsection{Empirical Review on Trade Facilitation and Cost of Operation}

Empirical studies on commercial policies relating to trade facilitation are limited but most of those illustrate the significance of burden associated with transport costs or other trade-related transaction costs, and hence potential trade or welfare gains from elimination of such costs. Some studies focus on a particular element of trade facilitation-such as customs and movement procedures while others model trade facilitation as efforts in multiple dimensions. Transport costs are inevitable in most of trade transactions, and usually constitute a dominant share of trade-related transaction costs. According to World Bank (2002), transport cost and transportation barriers in developing countries clearly outweighed tariff barriers A study by UNCTAD (2014) focuses on fees charged for road haulage, maritime and air transport services, and shows that a percentage reduction in the fees could reduce the cost of operation of the corporations involved as Nigeria is not an exception.

More transparent border procedures and regulations are particularly burdensome for the many multinational firms in developing countries, Azevedo, (2015) findings revealed that trade facilitation is a key element in reducing the cost of operation of multinational and that cost of operation is a major determinant of employability for certain multinationals. Also, Zaki (2011) discovered that efficient Trade facilitation process plays an important role in economic growth, poverty and inequality. Reduction in trade transaction costs can increase international trade. Together with economic globalization, trade tariffs tend to decrease over time. Reduction of non-tariff trade barriers has been receiving more attention from the governments and international agencies. A number of studies by Jensen and Tarr (2011)find a positive effect of trade facilitation on multinational cost of operation and the need of ensuring that trade can flow with minimum impediments, with higher security levels and more efficient government control methods.

\subsection{Research Method}

The research study adopted the Survey Research Method which involves the use of structured questionnaire designed to obtain data from respondents on their perception of Commercial Policy's trade facilitation and cost of operation as its affects employment in Nigeria's multinational corporations. The reason for the use of survey research method is that it was few researchers widely and commonly used in similar research of this nature (Deennis and Shepherd, 2011; Ahmed etal, 2012) and it's of better adoption in Nigeria's case because secondary data on commercial policies is limited. The study population cuts across all levels of employees in the multinational companies. The reason for this was based on the study of Ahmed etal (2012), who stated that majority on managerial and non-managerial employees are usually the ones with better understanding of the operations of commercial policies and employment processes in organizations. The study selected five multinational corporations in the South west that are homogenous in nature and are listed on the Nigerian Stock Exchange based Manufacturers Association of Nigeria (MAN) rectitude that about $70 \%$ of manufacturing firms are located in south west region. The hierarchical structure of the study population is made up of three tiers, which include Top, Middle and Low level employees. The characteristic of the study population was mixed at every level of the multinationals irrespective of gender, age, marital status, number of dependents, highest educational qualification, job status and years worked in the corporation.

Table 3.1. List of the selected multinational firms in the South West, Nigeria

\begin{tabular}{|l|l|l|l|l|l|l|}
\hline S/N & COMPANY & LOCATION & CEO & $\begin{array}{l}\text { EXECUTIVE } \\
\text { DIRECTORS }\end{array}$ & OFFICERS & $\begin{array}{l}\text { NO. OF SAMPLES FOR } \\
\text { EACH COMPANY }\end{array}$ \\
\hline 1 & PZ Cussons Plc & South West & 1 & 12 & 4,961 & 75 \\
\hline 2 & Unilever Plc & South West & 1 & 8 & 944 & 75 \\
\hline
\end{tabular}




\begin{tabular}{|l|l|l|l|l|l|l|}
\hline 3 & Cadbury Plc & South West & 1 & 6 & 727 & 75 \\
\hline 4 & Nestle Plc & South West & 1 & 9 & 2,325 & 75 \\
\hline 5 & Glaxosmithkline & South West & 1 & 7 & 419 & 75 \\
\hline & TOTAL & & $\mathbf{5}$ & $\mathbf{4 5}$ & $\mathbf{9 , 3 7 6}$ & $\mathbf{3 7 5}$ \\
\hline
\end{tabular}

Source: Researchers Compilation, (2017).

\subsection{Sample Size Determination}

The sample size for this study was determined using a software called MaCorr Sample Size Calculator. The calculator consisted of fields that allowed input of population size and level of significance. The sample size was determined with 9,367 employees using $95 \%$ as the confidence level, which meant we were $95 \%$ certain that the sample is real and repeatable. Below is a pictorial representation of MaCorr Sample Size Calculator in operation.

Fig. 3.1 (Step 1)

Fig. 3.2 (Step 2)

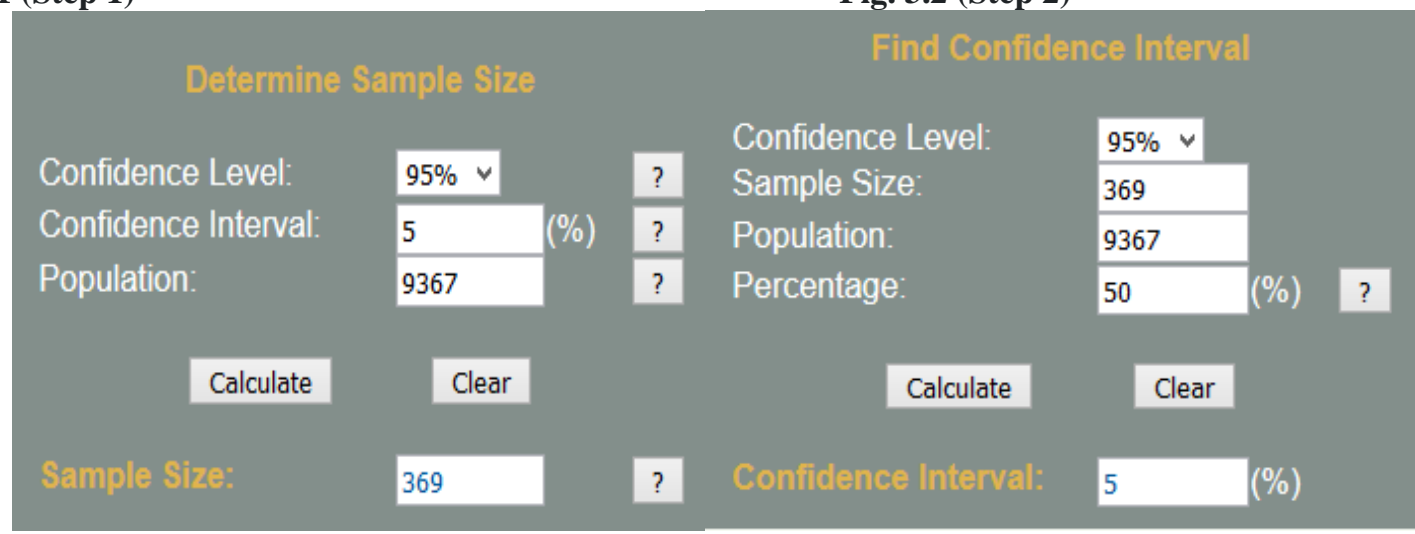

Source: www.macorr.com (Maccor Sample Size Calculator)

From Figs. $3.1-3.2,5 \%$ or 0.05 confidence level was selected with 5 entered at the confidence interval space, while the population size $(9,367)$ was entered in the population cell. When the "calculate" button was clicked, the sample size figure was generated at as shown in fig. 3.2. The sample size for this is 369 and represents the number of respondents across the multinational corporations to which copies of questionnaire will be administered. The use of the software was justified by professionals in various industries as stated in the website (http://www.macorr.com) from where the software was downloaded. The 60 professionals had made use of the software and it yielded their results. A comparison of results from the MaCorr Sample Size Calculator with those from conventional formulas, such as Yard and Yamane's formulas, showed no marked difference. The sample size of 369 employees will be spread among the 5 selected multinationals companies in Nigeria and respondents were selected randomly to give all the companies equal opportunities of being studied.

The sample size for this study was determined using the Yamane's sample size formula. Giving the population of 9,367 , a $95 \%$ confidence level and $\mathrm{P}=5 \%$ the equation is thus presented as:

$n=$

$\mathrm{N}$

$1+\mathrm{N}(e) 2$

Where $\mathrm{n}$ is the sample size, $\mathrm{N}$ is the population size, and "e" is the level of precision. The computed sample size therefore, using Yamane's formula was:

If $\mathrm{n}=$ Sample Size

$\mathrm{N}=9,367$ Employees

$e=5 \%$ or 0.05

$\mathrm{CL}=95 \%$

Therefore, $n=9,367$

$1+9,367(0.05)$

2

$\mathrm{n}=374.70$

$\mathrm{n}=\sim 375$ Employees 
Approximately 375 employees was derived as the sample size using the Yamane's sample size formula. This meant that averagely 70 copies of the questionnaire were to be administered in each of the multinational corporations. Justifying this, Maguire (2005) suggested that stratified sampling technique should be used in order to allow every element in a sample frame to have an equal chance of being chosen. The formula below was suggested: $n \mathrm{~h}=\mathrm{Nh} * n$ and $\mathrm{N}$. Where $n \mathrm{~h}$ is the sample size of each company. $\mathrm{Nh}$ is the population size of each corporation. $\mathrm{N}$ is the population of the study. $n$ is the sample size of the study.

\subsection{Presentation of Data}

The research questionnaire was administered to three hundred and seventy five (375) employees which is the sample size representing the chosen study population of the selected 5 multinational companies in Nigeria. Of this lot, three hundred and forty six (346) questionnaires representing $92.3 \%$ were returned, and twenty nine (29) questionnaires representing $7.7 \%$ were not returned.

\subsection{Frequency Distribution of the Respondents' Demographic Characteristics}

The frequency distribution of the respondents' demographic characteristics is presented in table 4.2 below. The table shows that out of the three hundred and forty six (346) respondents, $229(66.2 \%)$ are male, while 177 (33.8\%) are female. By implication, we have more male respondents to female respondents in the sample. Also, there are 98 M.SC and M.BA holders (28.3 per cent), $167 \mathrm{HND/BSc}$ holders (48.3 per cent), 350 level holders (10.1 per cent), in the sample. By implication, the respondents have high HND/BSc educational qualifications. In addition, out of the three hundred and forty six (346) respondents, 31(9.0\%) are single while $315(91.0 \%)$ are married. By implication, most of the respondents are married. Again, out of the three hundred and forty six (346) respondents, 41(51 years and above), 69 (19.9\%) are between 41 and 50 years of age, 123 (35.5\%) are between 31 and 40 years, and 113 (32.7) are between 20 and 30 years. By implication most of the respondents are between the age of 31 and 40 years. More so, 71 (20.5\%) of the 346 respondents are employees of PZ Cussons PLC, 69 (19.9\%) are employees of Unilever PLC, 73 (21.1\%) are employees of Cadbury PLC, 64 (18.5\%) are employees of GlaxoSmithKline and 69 (19.9\%) are employees of Nestle PLC. By implications, most of the respondents are employees of Cadbury PLC. More importantly, out of the 346 respondents, 97 (28.0\%) are top level managers; $173(50.0 \%)$ are middle level managers while $76(22.0 \%)$ are lower level managers. By implication, we have more of middle level managers as respondents in the sample.

Table 4.2: Frequency Distribution of the Respondents' Demographic Characteristics $(\mathrm{N}=346)$

\begin{tabular}{|l|l|l|l|l|}
\hline Characteristics & Category & Frequency & Percent & Cumulative percent \\
\hline Gender & Male & 229 & 66.2 & 66.2 \\
\hline & Female & 117 & 33.8 & 100.0 \\
\hline Educational Qualification & O Level & 35 & 10.1 & 10.1 \\
\hline & HND/BSc & 167 & 48.3 & 58.4 \\
\hline & MSC/MBA & 98 & 28.3 & 86.7 \\
\hline Marital status & Others & 46 & 13.3 & 100.0 \\
\hline & Married & 315 & 91.0 & 91.0 \\
\hline Age & Single & 31 & 9.0 & 100.0 \\
\hline & $20-30$ & 113 & 32.7 & 32.7 \\
\hline & $31-40$ & 123 & 35.5 & 68.2 \\
\hline & $41-50$ & 69 & 19.9 & 88.2 \\
\hline Company & 51 years above & 41 & 11.8 & 100.0 \\
\hline & Nestle PLC & 69 & 19.9 & 19.9 \\
\hline & Glaxosmithkline & 64 & 18.5 & 38.4 \\
\hline & Cadbury PLC & 73 & 21.1 & 59.5 \\
\hline & Unilever PLC & 69 & 19.9 & 79.5 \\
\hline Management Cadre & PZ Cussons PLC & 71 & 20.5 & 100.0 \\
\hline & Lower level & 76 & 22.0 & 22.0 \\
\hline & Middle level & 173 & 50.0 & 72.0 \\
\hline & Top level & 97 & 28.0 & 100.0 \\
\hline
\end{tabular}

Source: Author's Fieldwork Computation, 2017

\subsection{Descriptive Statistics of the Respondents' Perceptions}


The Descriptive Statistics of the Respondents' Perceptions is presented in table 4.3 below. Concerning trade facilitation, we have information from 346 respondents; the range of trade facilitation is from 2 to 4 points, with a mean of 3.30 and standard deviation of 0.577. By implication, the respondents, on average, agreed with questions on trade facilitation. Concerning skill availability, we have information from 346 respondents; the range of Skill Availability is from 1 to 4 points, with a mean of 3.06 and standard deviation of 0.606 . By implication, the respondents, on average, agreed with questions on skill availability. Concerning foreign ownership, we have information from 346 respondents; the range of foreign ownership is from 1 to 5 points, with a mean of 3.69 and standard deviation of 0.656 . By implication, the respondents are, on average, agreed with questions on foreign ownership. Concerning social infrastructural availability we have information from 346 respondents; the range of social infrastructural availability is from 1 to 5 points, with a mean of 3.51 and standard deviation of 0.662. By implication, the respondents are, on average, agreed with questions on social infrastructural availability. Concerning, cost of operation we have information from 346 respondents; the range of cost of operation is from 1 to 5 points, with a mean of 3.45 and standard deviation of 0.617. By implication, the respondents, on average, agreed with questions on cost of operation. Concerning, employment creation capacity we have information from 346 respondents; the range of employment creation capacity is from 1 to 4 points, with a mean of 3.06 and standard deviation of 0.606. By implication, the respondents, on average, agreed with questions on employment creation capacity. Concerning, locational strategy we have information from 346 respondents; the range of locational strategy is from 1 to 5 points, with a mean of 3.67 and standard deviation of 0.665 . By implication, the respondents, on average, agreed with questions on locational strategy. Concerning, corporate productivity we have information from 346 respondents; the range of corporate productivity is from 1 to 5 points, with a mean of 3.51 and standard deviation of 0.662. By implication, the respondents, on average, agreed with the questions on corporate productivity.

\begin{tabular}{|c|c|c|c|c|c|}
\hline Mean of Variables & $\mathbf{N}$ & Minimum & Maximum & Mean & Std. Deviation \\
\hline Trade Facilitation & 346 & 2 & 4 & 3.30 & 0.577 \\
\hline Skill Availability & 346 & 1 & 4 & 3.06 & 0.606 \\
\hline Foreign Ownership & 346 & 1 & 5 & 3.69 & 0.656 \\
\hline $\begin{array}{ll}\text { Social } & \text { Infrastructural } \\
\text { Availability } & \end{array}$ & 346 & 1 & 5 & 3.51 & 0.662 \\
\hline cost of operation & 346 & 1 & 5 & 3.45 & 0.617 \\
\hline $\begin{array}{l}\text { Employment } \quad \text { Creation } \\
\text { Capacity }\end{array}$ & 346 & 1 & 4 & 3.06 & 0.606 \\
\hline Locational Strategy & 346 & 1 & 5 & 3.67 & 0.665 \\
\hline Corporate Productivity & 346 & 1 & 5 & 3.51 & 0.662 \\
\hline Valid N & 346 & & & & \\
\hline
\end{tabular}

Source: Author's Fieldwork Computation, 2017

\subsection{Data Analysis Based on Hypotheses}

The hypotheses of the study are: (1) trade facilitation, foreign ownership, skill availability and social infrastructure availability does not significantly affect cost of operation of multinationals.; To test these hypotheses and achieve the objectives of the study, multiple regression analysis was used. Multiple regression is based on correlation but allows a more sophisticated exploration of the interrelationship among a set of variables. It makes a number of assumptions about the data which are

1. Normality: It is assumed that the dependent variable is normally distributed (i.e. employability 
2. Multicollinearity: It is assumed that the independent variables (Commercial Policy i.etrade facilitation, foreign ownership, skill availability and social infrastructure availability) are not highly correlated.

3. Homoscedasticity: It is assumed that the variations among observations is even.

4. Linearity: It is assumed that the relationship between dependent and independent variables is linear.

5.

\subsubsection{Test of Normality}

A normal curve was drawn to test for normality of the dependent variable (i.e. employability coefficient which are represented by cost of operation, employment creation capacity, locational strategy and corporate productivity). Fig 4.4.1.1 to 4.4.1.4 presents a normal curve of employability co-efficient scores. Many of the parametric statistics assume that the scores on each of the variables are normally distributed (i.e. follow the shape of the normal curve). In this study, the scores are reasonably normally distributed, with most scores occurring in the centre, tapering out towards the extremes.
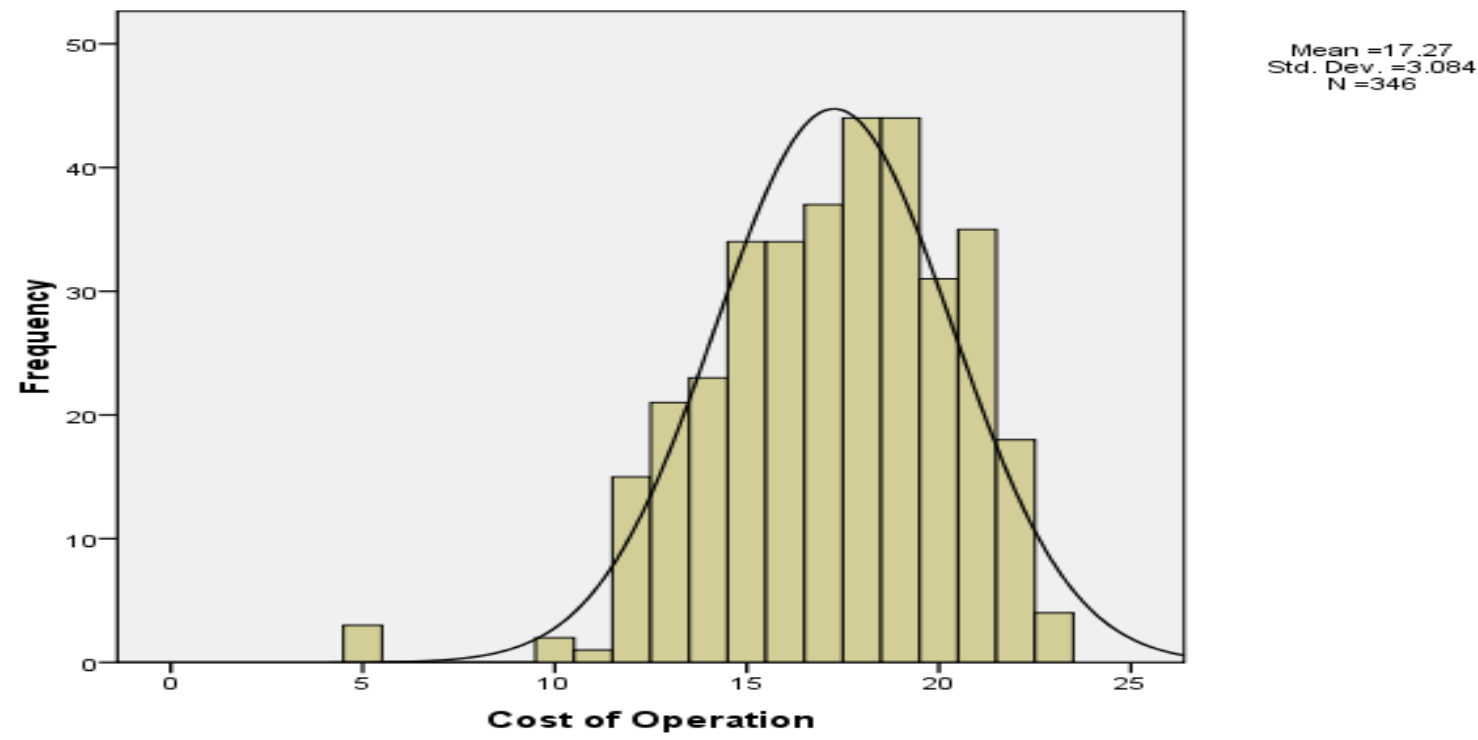

Fig 4.4.1.1: Histogram of Perceived cost of operation Scores

Source: Author's Fieldwork Computation, 2017

\subsubsection{Test of Multicollinearity}

Multicollinearity exists when the independent variables are highly correlated (that is $r=.7$ and above). Tabachnick and Fidell (2001) suggested that you 'think carefully before including two variables with a bivariate correlation of, 0.7 or more in the same analysis'. There is need to consider omitting one of the variables. To check for multicollinearity, bivariate correlation was conducted in Table 4.3 below. In the table, the highest correlation was .544. It shows low multicollinearity problem among CPI variables (trade facilitation, skill availability, foreign ownership and social infrastructural availability). Therefore, all the variables are retained.

\begin{tabular}{|l|l|l|l|l|l|}
\hline \multicolumn{2}{|l|}{ Table 4.4.2.1:Correlations among Commercial Policy Variables } \\
\hline \multirow{3}{*}{ Trade Facilitation } & $\begin{array}{l}\text { Trade } \\
\text { Facilitatio } \\
\mathrm{n}\end{array}$ & $\begin{array}{l}\text { Skill } \\
\text { Availability }\end{array}$ & $\begin{array}{l}\text { Foreign } \\
\text { Ownershi } \\
\mathrm{p}\end{array}$ & $\begin{array}{l}\text { Social } \\
\text { Infrastructural } \\
\text { Availability }\end{array}$ \\
& $\begin{array}{l}\text { Pearson } \\
\text { Correlation }\end{array}$ & 1 & & & \\
\cline { 2 - 6 } & Sig. (2-tailed) & & & & \\
\cline { 2 - 6 } & N & 346 & & & \\
\hline
\end{tabular}




\begin{tabular}{|l|l|l|l|l|l|}
\hline \multirow{5}{*}{ Skill Availability } & $\begin{array}{l}\text { Pearson } \\
\text { Correlation }\end{array}$ & -.057 & 1 & & \\
\cline { 2 - 6 } & Sig. (2-tailed) & .293 & & & \\
\cline { 2 - 6 } & $\mathrm{N}$ & 346 & 346 & & \\
\hline Foreign Ownership & $\begin{array}{l}\text { Pearson } \\
\text { Correlation }\end{array}$ & $.152^{* *}$ & -.006 & 1 & \\
\cline { 2 - 7 } & Sig. (2-tailed) & .005 & .906 & & \\
\cline { 2 - 7 } & $\mathrm{N}$ & 346 & 346 & 346 & \\
\hline $\begin{array}{l}\text { Social } \\
\text { Availability }\end{array}$ & $\begin{array}{l}\text { Pearson } \\
\text { Correlation }\end{array}$ & $.166^{* *}$ & $-.182^{* *}$ & $.544^{* *}$ & 1 \\
\cline { 2 - 6 } & Sig. (2-tailed) & .002 & .001 & & \\
\hline & $\mathrm{N}$ & 346 & 346 & .000 & \\
\hline
\end{tabular}

Source: Author's Fieldwork Computation, 2017

\subsubsection{Test of Homoscedasticity and Linearity for Hypothesis One}

A scatter plot could be drawn to test for homoscedasticity and linearity of the relationship between dependent variable (i.e. cost of operation, employability coefficient capacity, locational strategy, corporate productivity) and independent variable (i.e. trade facilitation, skill availability, foreign ownership and social infrastructural availability). Fig 4.4.3.1, 4.4.3.2, 4.4.3.3 and 4.4.3.4 present the output of scatter plots. From the output below, there appears to be a moderate, positive correlation among the variables. Respondents that are highly affected by trade facilitation, skill availability, foreign ownership and social infrastructural availability experience high levels of employability factors which include cost of operation, employability coefficient capacity, locational strategy, corporate productivity. On the other hand, employees with less affected by trade facilitation, skill availability, foreign ownership and social infrastructural availability have much higher levels of employability factors. There is no indication of a curvilinear relationship (test of linearity) and the scatter plot shows a fairly even cigar shape along its length (test of Homoscedasticity).

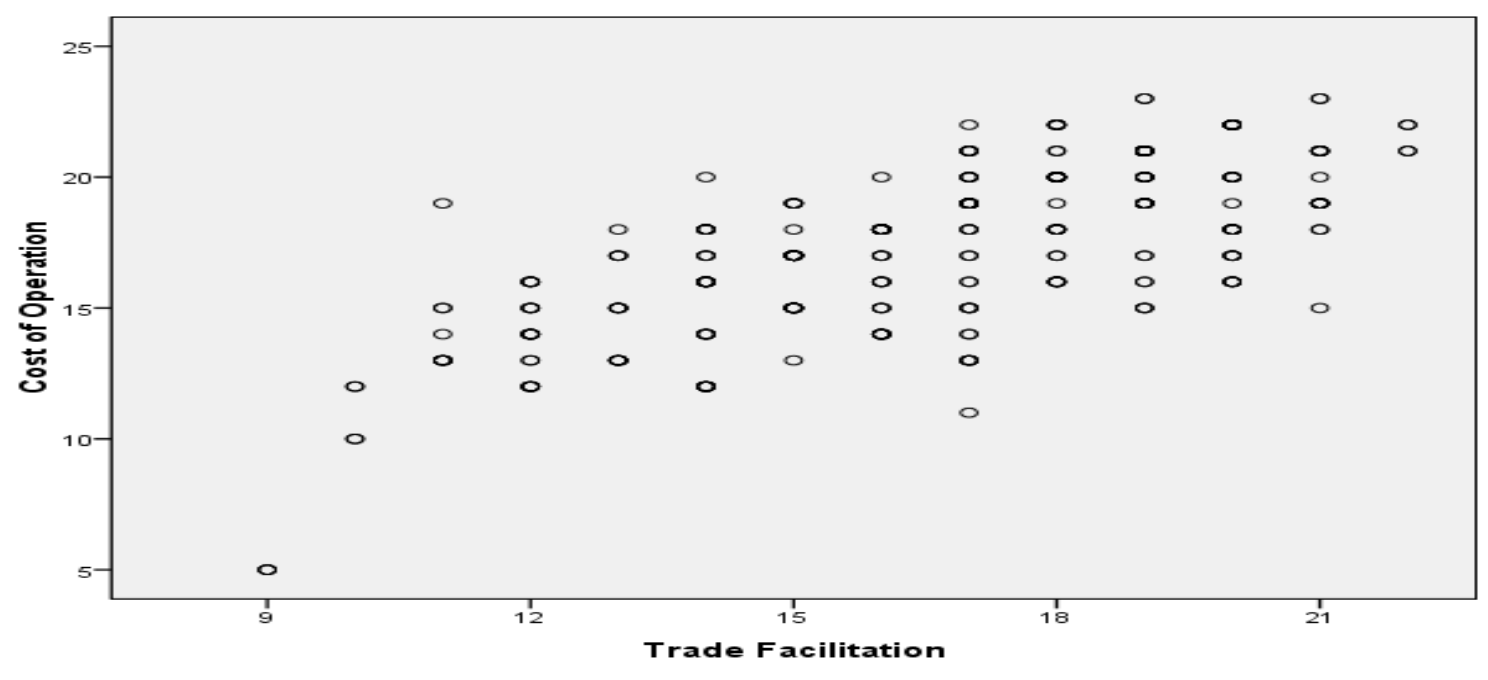


Fig 4.4.3.1.: Scatter Plot of Perceived trade facilitation and cost of operations Scores

Source: Author's Fieldwork Computation, 2017

\section{Test of Hypothesis One}

$\mathrm{Ho}_{1}$ : Trade facilitation, foreign ownership, skill availability and social infrastructure availability does not significantly affect cost of operation of multinationals.

Standard multiple regression was used to explore the effects of trade facilitation, foreign ownership, skill availability and social infrastructure availability on cost of operation of multinationals. Preliminary analyses were performed to ensure no violation of the assumptions of normality, Multicollinearity, homoscedasticity and linearity. The result of regression as contained inTable 4.4.3.1: ANOVA, shows that the F-test was 116.837, significant at 1 percent $[p<.000]$. This showed that the model was well specified.

Table 4.4.3.1

\begin{tabular}{|c|c|c|c|c|c|c|}
\hline \multicolumn{7}{|c|}{ ANOVA $^{b}$} \\
\hline \multicolumn{2}{|c|}{ Model } & Sum of Squares & Df & Mean Square & $\mathrm{F}$ & Sig. \\
\hline \multirow[t]{3}{*}{1} & Regression & 1897.495 & 4 & 474.374 & 116.837 & $.000^{\mathrm{a}}$ \\
\hline & Residual & 1384.508 & 341 & 4.060 & & \\
\hline & Total & 3282.003 & 345 & & & \\
\hline \multicolumn{7}{|c|}{$\begin{array}{ll}\text { a. } & \text { Predicto } \\
\text { b. } & \text { rs: (Constan } \\
& \text { Ownership }\end{array}$} \\
\hline \multicolumn{4}{|c|}{ b. Dependent Variable: Cost of Operation } & & & \\
\hline
\end{tabular}

Author's Fieldwork Computation, 2017

Also, the result of regression as contained in Table 4.4.3.2: Model Summary, shows that the R Square gave a large value of 57.8 per cent. This means that the model (which includes trade facilitation, foreign ownership, skill availability and social infrastructure availability) explained about 57.8 per cent of the variance in perceived cost of operation. The Durbin-Watson Statistic gives 1.918 coefficients which indicate that there is absence of serial correlation in the error terms of the model as such ruling out problems associated with spurious regressions.

Table 4.4.3.2

\begin{tabular}{|l|l|l|l|l|}
\hline \multicolumn{3}{|l|}{ Model Summary } \\
\hline Model & R & R Square & $\begin{array}{l}\text { Adjusted } \\
\text { Square }\end{array}$ & $\begin{array}{l}\text { Std. Error of the } \\
\text { Estimate }\end{array}$ \\
\hline 1 & $.760^{\mathrm{a}}$ & .578 & .573 & 2.015 \\
\hline $\begin{array}{l}\text { a. Predictors: (Constant), Social Infrastructural Availability, Trade } \\
\text { Facilitation, Skill Availability, Foreign Ownership }\end{array}$
\end{tabular}

Author's Fieldwork Computation, 2017

Specifically, the result of regression as contained in Table 4.4.3.3 Regression Coefficients, tests the four hypotheses of this study. From the output below, there was positive relationship between perceived trade facilitation and perceived cost of operation such that a unit increase in perceived trade facilitation scores caused about .724 unit increase in perceived cost of operation scores which was statistically significant at 1 per cent with the aid of the $p$ value (0.000). Based on the result, the null hypothesis is rejected; thus, there was positive relationship between trade facilitation and cost of operation. 
Also, although, there was positive relationship between perceived skill availability and perceived cost of operation such that a unit rise in perceived skill availability scores induced about .010 unit rise in perceived cost of operation scores which was statistically not significant at 1 per cent going by the p value $(0.781)$. Based on the result, the null hypothesis is accepted; thus, skill availability is not affected by cost of operation.

More importantly, there was positive relationship between perceived foreign ownership and perceived cost of operation such that a unit rise in perceived foreign ownership scores induced about 184 unit rise in perceived cost of operation scores which statistically significant at 1 per cent going by the $p$ value $(0.000)$. Based the result, the null hypothesis is rejected; thus, there was relationship between foreign ownership and cost of operation.

Furthermore, there was positive relationship between perceived social infrastructural availability and perceived cost of operation such that a unit rise in perceived social infrastructural availability scores induced about .074 unit rise in perceived cost of operation scores which was statistically not significant at 1 per cent going by the $p$ value $(0.066)$. Based on the result, the null hypothesis is accepted; thus social infrastructural availability did not affected cost of operation.

Table 4.4.3.3

\begin{tabular}{|c|c|c|c|c|c|c|}
\hline \multicolumn{7}{|c|}{ Coefficients $^{\mathrm{a}}$} \\
\hline \multirow{2}{*}{\multicolumn{2}{|c|}{ Model }} & \multicolumn{2}{|c|}{ Unstandardized Coefficients } & \multirow{2}{*}{$\begin{array}{l}\text { Standardized } \\
\text { Coefficients } \\
\text { Beta }\end{array}$} & \multirow[t]{2}{*}{$\mathrm{T}$} & \multirow[t]{2}{*}{ Sig. } \\
\hline & & $\mathrm{B}$ & Std. Error & & & \\
\hline \multirow[t]{5}{*}{1} & (Constant) & .486 & 1.069 & & .455 & .650 \\
\hline & Trade Facilitation & .724 & .038 & .678 & 18.940 & .000 \\
\hline & Skill Availability & .010 & .037 & .010 & .279 & .781 \\
\hline & Foreign Ownership & .184 & .040 & .195 & 4.619 & .000 \\
\hline & $\begin{array}{ll}\text { Social } & \text { Infrastructural } \\
\text { Availability } & \end{array}$ & .074 & .040 & .080 & 1.847 & .066 \\
\hline \multicolumn{3}{|c|}{ a. Dependent Variable: Cost of Operation } & & & & \\
\hline
\end{tabular}

\subsubsection{Discussion of Findings on Hypothesis}

The findings of this study has shown that reduction in bottlenecks of movement of goods across the states may be used to ameliorate the operational cost challenges of multinational corporations to be able to provide more employment opportunities for indigenes or locals of where there plants are sited as it has been situated in past researches by Rudaheranwa, (2006) and Denisia, (2010) that elements as Transport costs, road tariffs, undocumented levies and complex customs procedures are clearly an important element of trade costs which has its implications on employment generation capacity of corporations. UNCTAD (2014) highlighted fees charged for road haulage, maritime and air transport services, and showed that a percentage reduction in the fees could reduce the cost of operation of the corporations involved as Nigeria is not an exception. As such the implication of ease of doing business in Nigeria has a multiplier effects on cost of operation of companies as it sometimes limit the level of expansion of the firm to other territories which may later translates to creation of employment, In other words this research findings is tangential to past findings of scholars that have discovered that trade facilitation and its procedures have the tendencies to raise the cost of operation of firms.

\section{Theoretical Findings from the study}

(i) In the light of the importance and necessity that can be ascribed to commercial policies in relation with 
employability of multinationals; (Petri, 2012). It has become acceptable to broaden the discussion and analyses of policy issues beyond the purview of academic and policy statement, but shifting towards human capital development and employment generation dimensions as well as contextual issues with inference to the comparative advantage theory.

\section{Empirical Findings from the Study}

i. The study found that trade facilitation significantly affect cost of operation of multinationals indicating that when trade costs associated with transportation charges, undocumented levies, documentation requirements and delay in clearance; they tend to reduce their cost of operations because the strategy is adopted based on the notion that they are well competent to achieve the purpose which they are meant which will enable multinationals to recruit more qualified personnel into their organizations.

ii. It can be inferred that commercial policy affected operational costs well as the revenue generation, in terms of Movements hurdles encountered across several states that affect the physical distribution of products of multinational corporations in host countries. However, variations that were observed in the results among the firms implied the prevailing peculiarities in management operations, leadership style, strategy and structure of firms and the level of commercial policy exposure of the firms.

\section{Conclusion}

High response values for most of the variables under commercial policies implied that most of the firms in food and beverage and conglomerate sector complied with the commercial policy principles. In other words, the firms complied with commercial policy regulations. The results also derived from the responses collated for commercial policy intervention which also showed that multinationals are profits making entities that seek to minimize the costs of doing business, by moving to a developing economy to take advantage of lower labor costs and as such may be exploitative in areas where commercial policy are not people focused.

\subsection{Policy Recommendations}

i. The findings have established the relevance of commercial policy amongst Nigeria's multinational corporations. It is therefore necessary that all the firms within the sector should continue to adopt measures that would make commercial policies viable in their day to day activities.

ii. In addition, the global competitiveness of the sector hinges on effectively managing of employability outcomes that would culminate in favourable consequences such as cost reduction.

iii. The government is encouraged to continue to play her regulatory, facilitating and participatory roles to foster an enabling operating environment. This will contribute towards firm competitiveness in the domestic and global marketplace.

iv. It also important, to revisit applicable regulations in order to minimize areas of overlap so as to further ensure higher levels of compliance by the affected organizations. In addition, the practicality of the laws should be monitored especially in a nation like Nigeria that is still heavily reliant on expatriate efforts especially against the backdrop of the volatility of international economy indicators.

\section{REFERENCES}

[1] Alcacer, J. and Wilbur C. (2010).Location Strategies for Agglomeration Economies (Harvard Business School Working Paper No. 10-071). MA: Boston.

[2] Azevedo, R. (2015). It's Time to Seal the Deal on Global-Trade Reform.The Wall Street Journal.http://www.wsj.com/articles/its-time-to-seal-the-deal-on-global-k trade reform 1458071783 (accessed 30 May 2016).

[3] Aiyar, S., Duval, R., Puy, D., Wu, Y., \& Zhang, L.( 2013).Growth slowdowns and the middle income trap(IMF No. 13/71). Washington, DC: International Monetary Fund.

[4] De Hoyos-Ruperto, M., Romaguera, J. M., Carlsson, B., \& Perelli, S. (2012). Entrepreneurial Environment Dilemma in Puerto Rico: A Challenge of Self and System. Journal of Marketing Development and Competitiveness, 6, (3), 11-28.

[5] Dennis, A. and B. Shepherd (2011), 'Trade Facilitation and Export Diversification', World Economy, Vol. 34, No. 1, pp. 101-22. 
[6] Denisia, V. (2010). Foreign Direct Investment Theories: An Overview of the Main FDI Theories. European.Journal of Interdisciplinary Studies, 3, 53-59.

[7] Dunning, John H. 2009. Location and the multinational enterprise: John Dunning's thoughts on Receiving the Journal of International Business Studies 2008 Decade Award. Journal of International Business Studies, 40(1): 20-34.

[8] Ezie, O. (2012). Youth unemployment and its socio-economic implications in Nigeria. Journal of Social Science and Public Policy.4: 112-119. ISSN 2277-0038

[9] Hur, J and Park, C. (2012). Do Free Trade Agreements Increase Economic Growth of the Member Countries? World Development, 40 (7), 1283 - 1294.

[10] ILO-World of Work Report (2014).Developing with jobs/International Labour Office-ilo.org/global/research/globalreports/world-of-work/2014/lang--en/index.htm.

[11] Jensen, J. and D.G. Tarr (2011). Deep Trade Policy Options for Armenia: The Importance of Services, Trade Facilitation and Standards Liberalization. World Bank, World Bank Policy and Research Working Paper number 5662. http://econ.worldbank.org/external/default/main?pagePK=64165259\&theSitePK=469372\&piPK=64165421\&menuPK $=64166093$ \&entityID $=00015834920110518082525$

[12] Kweka, J. (2006), 'Trade and Transport Costs in Tanzania', School of Economics, University of Nottingham, CREDIT Research Paper 06/10.

[13] Milner, C., O. Morrissey and N. Rudaheranwa (2000), 'Policy and non-Policy Barriers to Trade and Implicit Taxation of Exports in Uganda', Journal ofDevelopment Studies, 37, 2, 67- 90.

[14] OECD Employment Outlook Statistics and Projections (2016) http://www.oecd.org/els/oecd employmentoutlook-19991266.htm.

[15] Okuyan, H.A., Ozun, A. \&Erbaykal, E. (2012). Trade openness and economic growth: further relying on data stationarity.International Journal of Commerce \& Management, 22(1),26-35.

[16] Persson, M. (2012). From Trade Preferences to Trade Facilitation: Taking Stock of the Issues, $\quad$ Economics. The
Open-Access, Open-Assessment E-Journal, 6(2), 2012-2017.

[17] Rudaheranwa, N. (2006). Trade and Transport Costs in Uganda(p. 06/09). University of $\quad$ Nottingham; School of Economics.

[18] UNCTAD (2014a).Key Statistics and Trends in International Trade 2014. I UNCTAD/DITC/TAB/2014-2.United Nations Conference on Trade and Development. Geneva.

[19] Zaki, C. 2014. "An empirical assessment of the trade facilitation initiative: econometric evidence and global economic effects," World Trade Review, 13(1): 103-30. 